\title{
Do labour market institutions matter? Micro-level wage effects of international outsourcing in three European countries
}

\author{
Ingo Geishecker • Holger Görg • \\ Jakob Roland Munch
}

(C) The Author(s) 2010. This article is published with open access at Springerlink.com

\begin{abstract}
This paper studies the impact of outsourcing on individual wages in three European countries with markedly different labour market institutions: Germany, the UK and Denmark. To do so we use individual-level data sets for the three countries and construct comparable measures of outsourcing at the industry level, distinguishing outsourcing by broad region. We discuss some possible intuitive reasons for why there may be differences in the impact of outsourcing across the three countries, based on labour market institutions.
\end{abstract}

Keywords International outsourcing · Individual wages ·

Labour market institutions

JEL Classification $\mathrm{F} 16 \cdot \mathrm{J} 31 \cdot \mathrm{C} 23$

\section{Introduction}

Over the last years globalisation and its alleged negative effects for the distribution of income, unemployment, poverty and social cohesion has caused immense public

\footnotetext{
I. Geishecker

Georg-August-Universität Göttingen, Germany, and Aarhus School of Business, Aarhus, Denmark

H. Görg

Kiel Institute for the World Economy, Christian-Albrechts-Universität Kiel, Germany, and CEPR, London, UK

J. R. Munch

University of Copenhagen and EPRU, Copenhagen, Denmark

I. Geishecker $(\bowtie)$

Faculty of Economic Sciences, Platz der Göttinger Sieben 3, 37073 Göttingen, Germany

e-mail: ingo.geishecker@wiwi.uni-goettingen.de
} 
anxiety in Europe, particularly against the backdrop of eastern enlargement of the European Union. Indeed, globalisation in the form of intensified international trade and, in particular, international outsourcing of production, has a deep structural impact fostering the specialisation of open economies in industries where they possess a comparative advantage. Other, less competitive industries on the other hand shrink. Following standard trade theory, international specialisation is expected to yield significant efficiency gains improving the welfare of open economies. ${ }^{1}$

However, even if there are overall welfare gains there will inevitably be distributional consequences leading to winners and losers of the globalisation process in the economy. This paper concerns itself with one aspect of globalisation, namely the practice of outsourcing of production around the globe. A key feature of today's globalisation process is the ever increasing international fragmentation of production resulting in outsourcing, that manifests itself in a fast growing share of trade with intermediate goods. What we witness now is a dramatically intensified international division of labour which does not only take place between industries but is prevalent within each manufacturing industry and increasingly within business services.

Trade liberalisation and technological progress have substantially lowered transaction costs which increasingly enables firms to outsource and relocate production to those locations where production costs are lowest. Analogue to conventional trade this outsourcing potentially yields large efficiency gains that materialise in the form of increased competitiveness and thus higher growth and employment. ${ }^{2}$ However, it is also clear that this process generates winners and losers. Particularly low-skilled workers in industrialised countries are arguably at risk to suffer higher economic insecurity, income losses, unemployment and social exclusion.

The aim of the paper is, hence, to try and identify winners and losers from international outsourcing in European economies. Specifically, we investigate the impact of outsourcing on wages of individual workers. A further aim of the paper is to establish whether the impact of international outsourcing differs across countries with different types of welfare states and, in particular, labour market institutions. In other words, we try to address the question as to what role labour market institutions may play in shaping the wage effect of international outsourcing on workers.

This makes our paper of particular relevance in the European context and highlights the importance of institutional characteristics of the labour market that affect the wage setting. Welfare states face the challenge of mitigating adverse effects of the globalisation process while at the same time the institutional characteristics of the welfare system directly shape the potential welfare gains and

\footnotetext{
1 Slightly newer trade models, however, have shown that the paradigm of universal welfare gains through international trade is heavily based on the assumptions of perfect competition and flexible factor prices. For example, Krugman (1995) shows that with rigid relative factor prices imports from low-wage countries cannot be met by a sufficient specialisation in export oriented activities. As a result, trade with low-wage countries can dramatically lower aggregate domestic production and employment.

2 See, e.g., Amiti and Wei (2009) and Görg et al. (2008).
} 
losses from international outsourcing. In the public but also academic debate one often refers to the European Social Model or the European Welfare System partly to contrast the American Social Model. However, institutional characteristics of the welfare system starkly differ within Europe. Somewhat simplifying, one can identify three types of social models within the European Union: the Anglo-Saxon, the Central European and the Scandinavian. All three substantially differ in terms of institutions and legislation particularly with respect to employment protection, unemployment benefits, minimum wages or the role of unions. The literature lacks detailed theories on how labour market institutions affect the impact of outsourcing on wages, so it is an open question that will be addressed empirically in this paper which social model is best suited to cope with the challenges of globalisation through outsourcing of production.

Empirical evidence so far suggests that low-skilled workers are the losers from international outsourcing of production in many countries. ${ }^{3}$ However, the existing empirical studies generally use fairly aggregated data which prevents an in-depth analysis of the social impact of this phenomenon. Namely, existing studies do not allow to separate changes in the composite demand for various skill groups in wage and employment effects. Furthermore, using aggregated data does not allow differentiating absolute gains and losses from relative ones. However, when designing policies it clearly matters whether the task is for instance to tackle increased income inequality that comes through absolute wage gains for highly educated workers or through absolute wage losses of low-skilled workers.

This paper provides a detailed disaggregated estimation of the impact of international outsourcing on individual wages for various population groups. We will identify winners and losers from the globalisation process and assess to what extent education and, thus, skills determine the individually experienced impact of globalisation. Although wages at the aggregate level are central determinants of social cohesion our micro level approach allows us to also look at other important factors. It is now not only possible to look at aggregated wage effects but also to assess the role of globalisation for individual economic security that manifests itself in annual income fluctuations.

The analysis is carried out for three countries: the United Kingdom, Germany and Denmark, that exemplary stand for the three different social models in Europe and significantly differ in terms of the institutional setting. Comparing the social impact of relocation across these three countries can provide interesting new insights into the role of institutions and social policies for shaping and mitigating the impact of globalisation.

Section 2 discusses briefly the theoretical background and the expected impact of labour market institutions on the relationship between international outsourcing and wages. Section 3 describes the empirical approach, measurement of outsourcing and micro data for the three countries. Estimation results are reported in Sect. 4. The final section offers a brief conclusion.

\footnotetext{
3 See for example Feenstra and Hanson (1996) on the US, Hijzen et al. (2005) on the UK and Geishecker (2006) on Germany.
} 


\section{International outsourcing, labour market institutions and wages}

In theory the consequences of outsourcing for workers of different skill types are not clear cut. For example, Feenstra and Hanson (1996) formulate a model of international outsourcing that is a specific form of a Heckscher-Ohlin (HO) type model with only one final good and two countries, North and South. By changing relative unit costs of production, for instance through Hicks-neutral technological progress in the South, production fragments with lower skill intensity are shifted from the North to the South, thereby raising the average skill intensity of production in both countries. As a result, relative demand for skilled labour increases in both the North and the South. By contrast, Arndt $(1997,1999)$ develops a model of international outsourcing that is also based on a $\mathrm{HO}$ framework but makes less restrictive assumptions. In particular, he considers trade between a small pricetaking economy and the rest of the world, allowing for two factors of production and two final goods. In this model, if the low-skill intensive industry shifts some fragments of production abroad, this results in a productivity improvement in the low-skill intensive industry and with given world prices, ultimately in higher relative wages for unskilled workers. Hence, depending on the models and assumptions chosen, outsourcing of the low-skill intensive part of production can lead to decreases or increases in the wage of (unskilled) labour in the outsourcing economy. ${ }^{4}$ Whether workers in practice gain or lose from fragmentation and relocation is, therefore, largely an empirical question.

These theoretical models assume that wages are flexible and that there is no unemployment. Furthermore, the two sector models assume that labour is mobile between industries. Clearly, these assumptions are generally violated in the real world, at least in the short run. This is where the role of labour market institutions comes into play. Many countries have, in some form or other, collective wage bargaining or coordination of wage bargaining, as well as some form of employment protection and unemployment benefits. This, on the one hand, leads to rigidities in the labour market but is also designed to safeguard workers against adverse shocks in the economy. However, to our knowledge there is a gap in the theoretical literature about what role labour market institutions play in shaping the effects of outsourcing on wages, so to provide some knowledge about the relationship we will as a first step assess empirically how outsourcing affects wages in the three countries under consideration. Nevertheless, based on a description of how labour market institutions work in United Kingdom, Germany and Denmark we will try to outline some plausible relationships and predictions.

Of the three countries considered, Germany has arguably the least flexible labour market institutions. In terms of employment protection, Germany has an elaborate system of legal rules and contracts that stipulate conditions for dismissal, providing fairly secure employment prospects for workers, but making hiring and firing of workers difficult for firms. In fact, as Nickell et al. (2005) show, Germany has one of the highest levels of employment protection among OECD countries. Furthermore, the German labour market is characterised by the importance of unions in

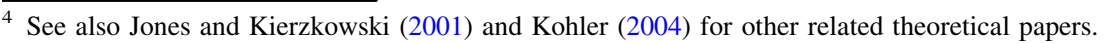


wage bargaining. While the actual level of unionisation is only about 30 percent of employees, the percentage of employees who are covered by wage bargaining is around 90 percent (Nickell et al. 2005). Collective bargaining generally takes place annually between unions and employer federations and can be at either industry and/ or regional level. ${ }^{5}$ It is important to note, however, that in collective bargaining only minimum wages are determined, while many workers are paid wages above that floor rate.

Compared to Germany, the UK represents the other, more flexible, end of the spectrum in terms of European labour market institutions. The level of employment protection is one of the lowest among OECD countries (with only the US and Canada being more flexible) and it also has substantially lower levels of union density and coverage than most other continental European countries (Nickell et al. 2005). Indeed, wage setting is generally decentralised and is relatively free of regulations, as discussed in some detail by Borland et al. (2002). The UK has adopted a system of a national minimum wage in 1999.

Turning to Denmark, an important characteristic of the labour market is that it is heavily unionised and although a process of decentralisation of wage formation has been ongoing since the late 1980's the wage structure is still relatively compressed even by European standards. Compared to other continental European labour markets the Danish labour market is often described as being very flexible as employment protection is relatively weak, while at the same time replacement rates of unemployment insurance (UI) benefits are high. A third distinguishing characteristic of the Danish labour market is that large sums are spent on active labour market policies. Together these ingredients form what by some has been dubbed the 'flexicurity' model. The idea behind this model is that Danish firms relatively easily may adjust employment according to demand. As compensation for high job turnover workers receive relatively generous UI benefits when unemployed, but incentives to search for jobs during unemployment are reinforced by a strict 'activation' regulation.

This labour market model has led to turnover rates and an average tenure which are in line with those of the Anglo-Saxon countries. In 1995 the average tenure in the Danish labour market was the lowest in continental Europe with 7.9 years just exceeding the number for the UK (7.8 years) while average tenure in the German labour market was 9.7 years (OECD 1997). Motivated by the fact that unemployment in Denmark is very low, OECD (2005) has recently recommended Germany to learn from the Danish 'flexicurity' model in its attempt to combat unemployment.

Table 1 summarises some important characteristics for the labour markets in (West) Germany, the UK and Denmark, which are taken from Nickell et al. (2005). The wage setting processes are clearly important to our analysis, and they are evidently following different mechanisms in the three countries. Wage formation in the UK is very flexible as union density, collective bargaining coverage and union co-ordination are lowest in the UK. In contrast, unions play a much more important role in the German and Danish labour markets-union density is highest in

\footnotetext{
5 See also Bender et al. (2002) for a good description of labour market institutions in Germany.
} 
Table 1 Labour market characteristics, 1994-1999

\begin{tabular}{llll}
\hline & Germany $(\mathrm{W})$ & UK & Denmark \\
\hline Union density (\%, 1996-1998) & 27 & 35 & 76 \\
Collective bargaining coverage (\%, 1994) & 92 & 40 & 69 \\
Co-ordination index (1995-1999) & 2.5 & 1.0 & 2.0 \\
Employment protection index (1998) & 1.30 & 0.35 & 0.70 \\
UI replacement ratio (1999) & 0.37 & 0.17 & 0.66 \\
Expenditure on ALMP (\% of GDP, 1998) & 1.26 & 0.34 & 1.66 \\
\hline
\end{tabular}

Source: Nickell et al. (2005)

Denmark while the coverage rate is highest in Germany, and wage bargaining in both countries is highly coordinated. Thus based on these observations we should expect that wages are most sensitive to changes in international outsourcing at the industry level in the UK.

However, this is not the complete picture since adjustments may go through employment changes instead. Coupled with the average tenures cited above it is clear that employment protection stands out as the most restrictive in Germany. Therefore the German labour market may be seen as the least flexible as wages are relatively rigid and employment is protected. The UK in contrast is the most flexible of the three economies with very little regulation of employment and wages, while Denmark is in between with rigid wage formation and low employment protection.

A possible expectation concerning the differential impact of outsourcing in the three countries is that wages should be least affected in Denmark, since with rigid wages adjustments are likely to go through employment changes instead. International outsourcing may give rise to wage moderation in bargaining between firms and unions if, for example, it corresponds to improved outside options for employers. This may be especially true for labour markets such as the German where employment is highly protected and thus cannot easily adjust. Thus even if wages are relatively rigid in Germany they may still adjust if faced with increasing outsourcing pressure. Furthermore, it is important to recall that centralised bargaining only determines the minimum level of wage, while most workers are paid above that level. Hence, wages may adjust by moving towards the minimum. In the UK both wages and employment may adjust so it is not entirely clear which dimension any adjustment may follow. Thus one may expect wages to be relatively insensitive to international outsourcing in Denmark, while they are more likely to adjust in Germany and the UK. In the following sections we address this question empirically in order to get a first impression of what the data tell us.

\section{Methodology}

To assess the impact of outsourcing on individual wages we follow the approach in Geishecker and Görg (2008) and Munch and Skaksen (2009) and estimate simple Mincer human capital wage equations of the form 


$$
\log w_{i j t}=\alpha+\beta X_{i t}+\gamma Y_{j t}+\lambda \mathrm{OUT}_{j t-1}+\mu_{t}+\alpha_{i}+l_{j}+\epsilon_{i j t},
$$

where $w_{i j t}$ is the hourly wage of worker $i$ in industry $j$ at time $t . X_{i t}$ is a vector of standard demographic and human capital variables which includes age, age squared, dummies for the presence of children and being married, job tenure, tenure squared, an indicator variable for high education, dummies for occupation using the nine main categories of the ISCO code, dummies for firm size and regional dummies. Year effects, $\mu_{t}$, and individual specific fixed effects, $\alpha_{i}$, are also controlled for. In addition we include industry dummies $l_{j}$, and to control for time varying industry characteristics and industry-specific technological progress we also enter industry output, $Y_{j t}$, and industry research and development intensity, R\&D/Y, in the model. The main explanatory variable of interest, of course, is the outsourcing variable, $\mathrm{OUT}_{j t-1}$, which we describe in more detail below. Industry level variables such as outsourcing are likely exogenous to the individual worker, but if there are industry components in individual wages (e.g. through collective bargaining) there may still be some endogeneity. We use the lagged value of outsourcing as a simple approach to alleviate any such problems.

All the regressions are weighted using the standard sampling weights from the respective data sets to adjust for different individual sampling probabilities. Finally a methodological point should be mentioned. In the wage Eq. 1 we estimate the effect of an aggregate variable (i.e. outsourcing at the industry level) on wages of individual workers, so the standard errors of the estimated coefficients may be biased downwards as indicated in Moulton (1990). Accordingly, we adjust standard errors allowing for contemporaneous correlation as has become standard in the literature.

\subsection{Measurement of international outsourcing}

Anecdotal evidence on firms shifting production stages abroad by subcontracting legally independent suppliers or establishing foreign production sites is manifold. However, systematically measuring the process of international outsourcing presents a challenge. Ideally one would want firm-level measures of outsourcing, but such information is rarely available and this is also the case for the three countries under consideration here. Instead we follow most of the literature and construct outsourcing measures at the industry level.

Most authors rely on trade statistics, exploiting the close relation between international outsourcing and trade in intermediate goods. Authors such as Yeats (2001) seek to measure international outsourcing or, as he calls it, production sharing, by directly quantifying trade in intermediate goods, assessing the intermediate character of the traded goods on the basis of disaggregated goods classifications. However, such calculations most likely are upward-biased, as imported parts and components (of machinery and transport equipment) are assumed to be intermediate goods imports of the respective broader industry that produces such parts and components itself (machinery and transport equipment industry). This abstracts from the possibility that parts and components from one industry can be also used by other manufacturing and service industries or by final 
consumers. Having said that, at the country level, differentiating trade in intermediate goods arguably is a valid way to derive a broad picture of the overall outsourcing intensity. However, in order to generate industry-level outsourcing measures, one needs to find ways to appropriately allocate imports of parts and components to those industries that actually use them.

Authors such as Feenstra and Hanson (1999) or Campa and Goldberg (1997) quantify international outsourcing by combining input coefficients that can be found in input-output tables and trade data. The estimated value of imported intermediate inputs of an industry thereby largely depends on whether one applies a narrow or wide definition of international outsourcing.

Campa and Goldberg (1997) assume that the total sum of imported intermediate goods in each industry as a share of the respective industry's production value represents a reasonable indicator for international outsourcing. However, according to Feenstra and Hanson (1999) the above definition might be too broad if one understands international outsourcing to be the result of a make-or-buy decision. Following this approach, it is not the total sum of imported intermediate inputs but only the part that could be produced within the respective domestic industry that actually constitutes international outsourcing. However, depending on the aggregational level, the range of products that an industry can produce varies. Accordingly, the more highly aggregated the industries are, the broader the definition of international outsourcing becomes.

For the present analysis we loosely follow the concept proposed in Feenstra and Hanson (1999) and measure narrow international outsourcing as the shift of a twodigit industry's core activities abroad, represented by the value of the industry's imported intermediate inputs from the same industry abroad as a share of the domestic industry's production value. The challenge is now to measure the respective industry's imports of intermediate goods. A simple procedure would be to assume that all imports from a certain foreign industry $i^{*}$ are directed towards the respective domestic industry $i$ and nowhere else. Essentially, this would amount to the construction of industry-level import penetration ratios, which are however rather poor measures of industries' outsourcing activities. Instead, input-output data that are available from national Statistic Offices are utilised in order to allocate imports according to their usage as input factors across industries. The use of inputoutput tables renders obsolete the differentiation of intermediate goods on the basis of disaggregated goods classifications. Imports are always counted as intermediate goods imports if they are used in manufacturing.

Formally, outsourcing is constructed as:

$$
\mathrm{OUTS}_{i t}=\frac{I M P_{i^{*} t} \times \Omega_{i i^{*} t}}{Y_{i t}}
$$

with $\mathrm{IMP}_{i^{*} t}$ denoting imported intermediate inputs from industry $i^{*}$ and $Y_{i t}$ the production value of industry $i$ at time $t . \Omega_{i i^{*} t}$ denotes the share of imports from a foreign industry $i^{*}$ that is consumed by the respective domestic industry $i$ in $t$ with $\sum_{i=1}^{I} \Omega_{i i^{*} t} \times I M P_{i^{*} t}=$ total imports from industry $i^{*}$ which are not only used in manufacturing but also in agriculture, services, private and public consumption, investment and exports in $t$. 
Table 2 Availability of input-output data

\begin{tabular}{llc}
\hline Country & Separate I-O tables for imports \\
\hline United Kingdom & Not available & $\begin{array}{c}\text { Instead aggregated } \\
\text { yearly tables 1992-2004 }\end{array}$ \\
Denmark & Available & 1990-2002 \\
Germany & Available & $1991-2000$ \\
\hline
\end{tabular}

Accordingly, we construct industry-level outsourcing measures for each country. In doing so we are, however, constrained by different availability of input-output tables for the different countries. While for Denmark use tables for imported inputs are available from 1990 to 2002, for Germany comparable tables are only available for 1991 until 2000. ${ }^{6}$

For the UK data availability is even more limited as input-output data differentiating between imports and domestic production is only available for $1995 .{ }^{7}$ Accordingly we use available yearly input-output tables from UK National Statistics which, however, do not differentiate between imports and domestic supplies. Table 2 summarises these constraints. In order to estimate our empirical model for a common period with as many years as possible we select the years 1991 until 2000 as joint sample period and for the UK use 1992 values of $\Omega$ for the missing year 1991.

Table 3 presents international outsourcing as weighted averages over all manufacturing industries in the UK, Denmark and Germany as well as corresponding growth rates. Generally speaking, the level of international outsourcing is roughly comparable across the three countries ranging from six to seven percent in 1999. In terms of total growth of international outsourcing, which is of course more meaningful than the sheer level, the UK stands out. Here outsourcing grew by about $49 \%$ over the years 1991 to 1999 . In comparison growth rates in Germany and Denmark are somewhat lower, but with $30 \%$ and $25 \%$ still substantial.

By differentiating imports by their origin while assuming $\Omega_{i i^{*} t}$ to be constant across import origins we can in a next step construct outsourcing measures for different geographic regions. Against the backdrop of dramatic political and economic change we are particularly interested in outsourcing towards Central and Eastern European Countries (CEEC) but also towards low-wage countries in Asia.

Equation 2 can then be separated geographically:

$$
\mathrm{OUTS}_{i t}=\frac{\sum_{c=1}^{C} I M P_{i^{*} c t} \times \Omega_{i i^{*} t}}{Y_{i t}}
$$

\footnotetext{
${ }^{6}$ In 2007 the German Federal Statistical Office released a major update of input-output tables, however only for the years from 1995 onwards. The present analysis is restricted to the 1990s. We therefore only utilize the initial release for the years 1991-2000.

7 Input-output data for the UK in this respect are similar to that for the US which also do differentiate between imports and domestic production.
} 
Table 3 Outsourcing intensity (per cent)

\begin{tabular}{|c|c|c|c|c|c|}
\hline Year & World & CEEC & LwAsia & HwOECD & RoW \\
\hline \multicolumn{6}{|l|}{ Germany } \\
\hline 1991 & 5.25 & 0.10 & 0.31 & 4.45 & 0.39 \\
\hline 1992 & 5.40 & 0.13 & 0.31 & 4.59 & 0.37 \\
\hline 1993 & 5.13 & 0.23 & 0.36 & 4.26 & 0.28 \\
\hline 1994 & 5.35 & 0.28 & 0.40 & 4.35 & 0.32 \\
\hline 1995 & 5.93 & 0.38 & 0.44 & 4.74 & 0.37 \\
\hline 1996 & 5.71 & 0.38 & 0.44 & 4.56 & 0.33 \\
\hline 1997 & 6.31 & 0.47 & 0.47 & 5.00 & 0.37 \\
\hline 1998 & 6.69 & 0.56 & 0.47 & 5.26 & 0.40 \\
\hline 1999 & 6.84 & 0.63 & 0.51 & 4.90 & 0.80 \\
\hline Growth rate & 30.33 & 546.21 & 64.26 & 10.11 & 104.54 \\
\hline \multicolumn{6}{|c|}{ United Kingdom } \\
\hline 1991 & 4.10 & 0.02 & 0.22 & 3.49 & 0.38 \\
\hline 1992 & 4.45 & 0.02 & 0.25 & 3.71 & 0.47 \\
\hline 1993 & 4.71 & 0.04 & 0.33 & 3.69 & 0.64 \\
\hline 1994 & 5.08 & 0.06 & 0.36 & 4.15 & 0.51 \\
\hline 1995 & 5.23 & 0.07 & 0.39 & 4.27 & 0.50 \\
\hline 1996 & 5.49 & 0.07 & 0.47 & 4.30 & 0.65 \\
\hline 1997 & 5.79 & 0.08 & 0.56 & 4.82 & 0.32 \\
\hline 1998 & 6.31 & 0.09 & 0.66 & 5.19 & 0.37 \\
\hline 1999 & 6.11 & 0.09 & 0.63 & 4.67 & 0.72 \\
\hline Growth rate & 48.92 & 430.85 & 193.91 & 33.76 & 89.94 \\
\hline \multicolumn{6}{|l|}{ Denmark } \\
\hline 1991 & 4.94 & 0.09 & 0.26 & 3.22 & 1.37 \\
\hline 1992 & 4.90 & 0.10 & 0.25 & 3.14 & 1.42 \\
\hline 1993 & 4.43 & 0.08 & 0.20 & 2.91 & 1.23 \\
\hline 1994 & 4.97 & 0.11 & 0.20 & 3.23 & 1.44 \\
\hline 1995 & 5.67 & 0.12 & 0.18 & 3.98 & 1.39 \\
\hline 1996 & 6.27 & 0.12 & 0.20 & 4.40 & 1.54 \\
\hline 1997 & 6.57 & 0.12 & 0.20 & 4.82 & 1.43 \\
\hline 1998 & 6.50 & 0.11 & 0.21 & 4.76 & 1.41 \\
\hline 1999 & 6.18 & 0.13 & 0.17 & 4.41 & 1.47 \\
\hline Growth rate & 25.07 & 34.68 & -33.55 & 37.11 & 7.36 \\
\hline
\end{tabular}

with $I M P_{i^{*} c t}$ denoting imported inputs from industry $i^{*}$ in the country of origin $c$ and $Y_{i t}$ the production value of industry $i$ at time $t$.

To account for potentially heterogenous effects we differentiate between outsourcing towards four economic regions: CEEC, low-wage Asia (LwAsia), high-wage OECD (HwOECD) and all other countries in the rest of the World 
(RoW). ${ }^{8}$ The respective figures are reported in Table 3. As becomes apparent, the intensity of outsourcing towards CEEC significantly differs between the three countries with Germany's outsourcing intensity towards CEEC in 1999 being more than four times higher than that of Denmark and the UK. Also in terms of growth rates, Germany is leading with a total growth rate of $546 \%$, swiftly followed by the UK with total growth of $431 \%$. Clearly, such figures are impressive; one has, however, to bear in mind, that outsourcing almost started from zero in 1991.

With respect to outsourcing towards low-wage countries in Asia, the UK shows the highest intensity closely followed by Germany and in some distance Denmark. Also in terms of growth of outsourcing towards low-wage Asia the UK is with a total growth rate of $194 \%$ most dynamic, followed by Germany while Danish firms substantially reduced their respective outsourcing intensity.

\subsection{Individual-level data}

We measure wages and worker characteristics using individual-level data for the three countries. The nature of data sets we use differs to some extent as data for the UK and Germany are based on surveys while data for Denmark come from administrative registers. However, in all cases we look at individual panel data for the period 1991-2000, and we restrict the samples to include only 18-65 year old male manufacturing workers. Special attention has been paid to construction of the explanatory variables in a consistent way across countries. For example, the education variable 'High education' is defined as the two highest categories in the International Standard Classification of Education (ISCED), which corresponds to the individual having tertiary education.

For Germany, the analysis is based on individual-level data from the German Socio Economic Panel (GSOEP). Specifically, the analysis is based on data from Sample A, B, C, D and E. ${ }^{9}$ We exclude respondents who report to work in East Germany as wages in the East are to a large extent shaped by the dramatic structural change of the economy that has been taking place since the fall of the wall and that dominates the impact of other changing structural factors such as outsourcing. Wages are defined as average hourly gross labour earnings including bonuses, premia and other extra payments over the year preceding the respective interview month.

For the UK, data come from the Britsh Household Panel Survey (BHPS), a household survey that follows the same representative sample of individuals over time. Again, as for Germany wages are defined as average hourly gross labour

\footnotetext{
${ }^{8}$ CEEC are: Bulgaria, Czech Republic, Estonia, Hungary, Latvia, Lithuania, Poland, Romania, Slovak Republic, Slovenia. LwAsia comprises: Bangladesh, Cambodia, China, India, Indonesia, Korea, Laos, Malaysia, Philippines, Taiwan, Thailand, Vietnam but also Hong Kong and Singapur as they are important trade intermediaries. HwOECD countries are all OECD countries except CEEC, Korea, Mexico and Turkey.

9 See Haisken-DeNew and Frick (2003) for a detailed description of the panel. The GSOEP data used in this paper were extracted using the Add-On package PanelWhiz for Stata. PanelWhiz (http://www. PanelWhiz.eu) was written by Dr. John P. Haisken-DeNew (john@PanelWhiz.eu). See Haisken-DeNew and Hahn (2006) for details. The PanelWhiz generated DO file to retrieve the data used here is available on request. Any data or computational errors in this paper are our own.
} 


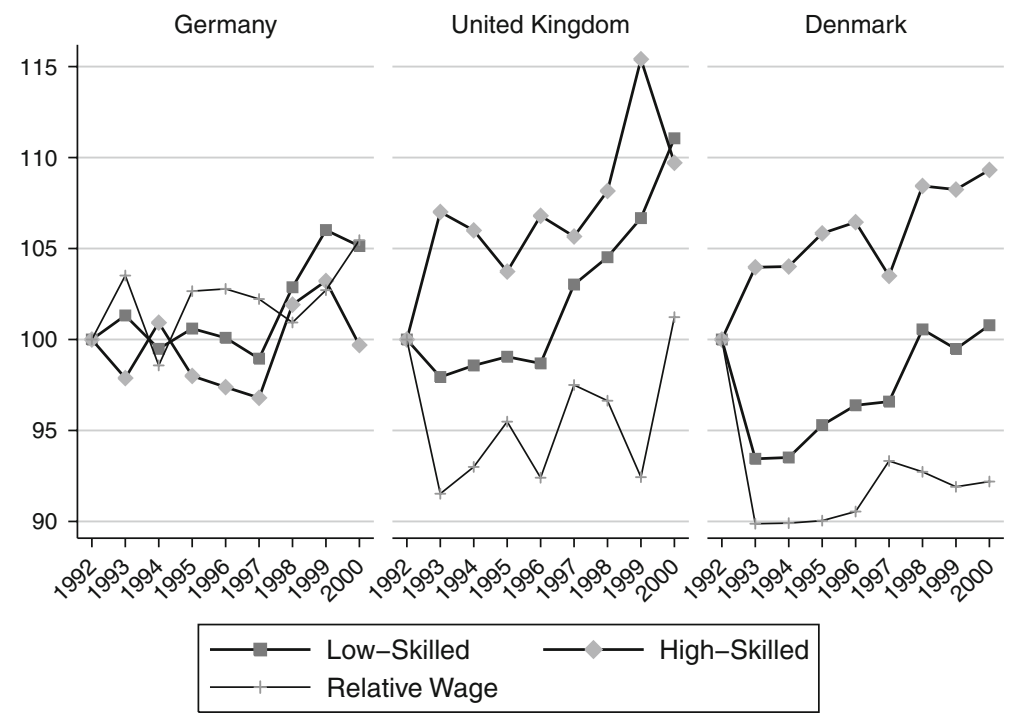

Fig. 1 Median wages by country

earnings including bonuses, premia and other extra payments over the year preceding the respective interview month.

For Denmark, the analysis relies on a large data set which is extracted from the Integrated Database for Labour Market Research (IDA) and the Income Registers in Statistics Denmark. There is information about individual characteristics for a $10 \%$ sample of workers in Danish manufacturing industries, and since the data is based on administrative registers its reliability is highly regarded. The hourly wage rate is calculated as total labour income divided by the total number of hours worked in any given year.

Figure 1 charts the development of median wages for high- and low-skilled workers, as well as the relative wage of unskilled workers to skilled workers, for the three countries over the period of analysis. The wages are expressed as indices with the levels in 1992 corresponding to 100 . What is notable is that for the UK and Denmark we see increases in the wage for skilled workers outstripping that for lowskilled workers. For Germany there is no such clear picture. Of course, these aggregate tables hide a lot of variation at the micro level. In order to examine the link between outsourcing and individual wages we, therefore, turn to econometric estimations of variants of Eq. 1 for the three countries under consideration.

\section{Estimation results}

In this section we present the results from estimating Eq. 1 for all three countries. Columns (1), (3) and (5) in Table 4 report the baseline results for Germany, the UK and Denmark, respectively. Focussing on the coefficient on international outsourcing we find that there is a small negative and weakly statistically significant effect 


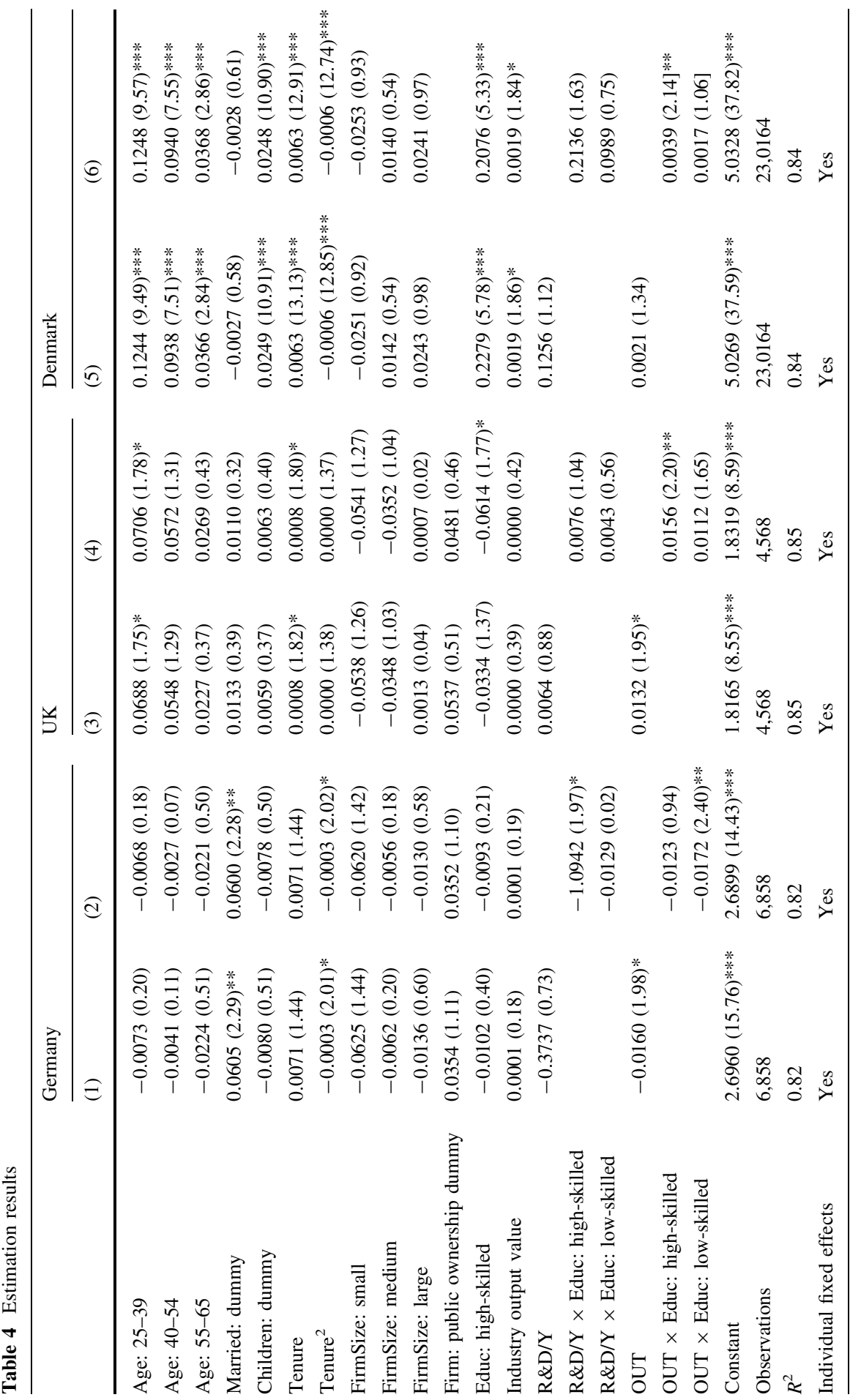




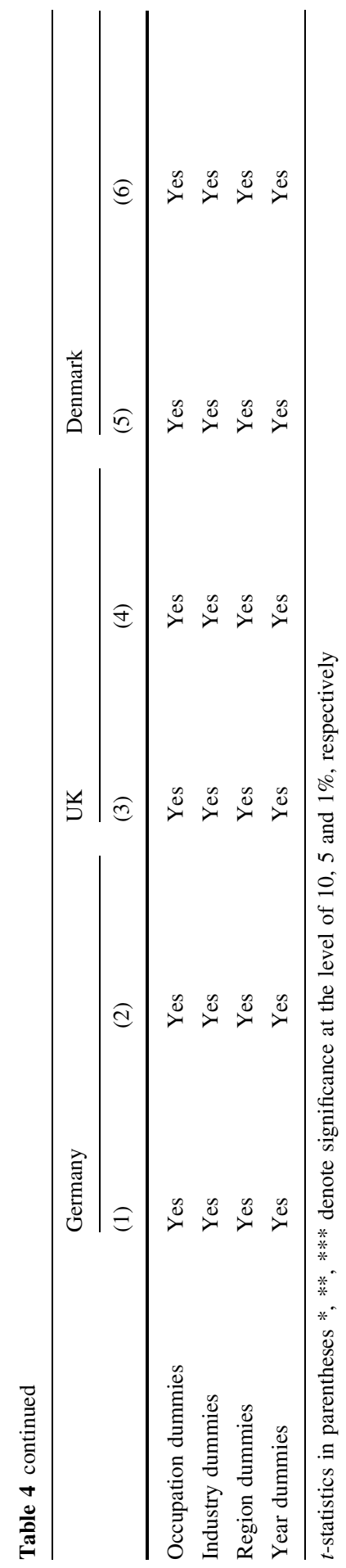


on wages for Germany. An one percentage point increase in German outsourcing intensity lowers average German manufacturing wages by about 1.6 percent. Thus, the overall demand effect of outsourcing is very small, which also becomes apparent when looking at the cumulative wage effect of outsourcing between 1991 and 1999. From Table 3 we know that over the sample period average outsourcing increased by 1.6 percentage. Hence outsourcing cumulatively reduced wages by about 2.5 percent.

For the UK aggregated outsourcing appears to have the opposite effect. An one percentage point increase in outsourcing ceteris paribus raises UK wages by on average 1.3 percent. Over the sample period outsourcing in the UK increase by 2 percentage points. Accordingly, the cumulative effect of UK outsourcing over the sample period is a 2.7 percent increase in average wages. For Denmark we fail to find any statistically significant coefficient.

While this regression controls for the skill level of the worker, it does not allow the effect of outsourcing to differ according to skills. However, from theory we may expect different effects: if countries outsource mainly low-skill production activities then in partial equilibrium the demand for low-skilled workers falls, bringing with it a reduction in the wage for these types of workers.

In order to allow for differential effects we interact the outsourcing variable with dummy variables for high- and low-skilled workers, respectively. These results are reported in Columns (2), (4) and (6) in Table 4.

We find that the negative effect found in the previous estimation for Germany only accrues to low-skilled workers. There is no statistically significant effect of outsourcing on high-skilled workers in Germany. Hence, this suggests that in Germany wages for low-skilled workers adjust downward in response to increased international outsourcing. Accordingly, in Germany on average an one percentage point increase in the outsourcing intensity lowers wages for low-skilled workers by a little more than one percent. ${ }^{10}$

In the UK, however, our results indicate that the previously identified positive wage effect of outsourcing is limited to high-skilled workers. Cumulatively outsourcing leads to high-skilled wage increases of on average three percent. For low-skilled UK workers we cannot identify an outsourcing effect with sufficient precision.

Similarly, when differentiating between different skill groups in Denmark we find that outsourcing raises high-skilled workers wages while the coefficient for low-skilled workers is statistically insignificant. The positive wage effect is, however, very small. An one percentage point increase in outsourcing raises highskilled wages by 0.4 percent. Cumulatively this amounts to a 0.5 percent wage increase for high-skilled workers due to aggregate outsourcing.

In the estimations thus far we treat outsourcing across regions as one homogeneous activity. Clearly, this is not the case. In order to allow for some

\footnotetext{
${ }^{10}$ The result of a negative effect for low-skilled workers is in line with Geishecker and Görg (2008). However, they also find a positive effect of outsourcing for high-skilled workers. This is likely to be due to their using more control variables and a finer skill classification, distinguishing three skill types, in the empirical model. This was not possible in our case in order to ensure that we estimate the same model for all three countries.
} 


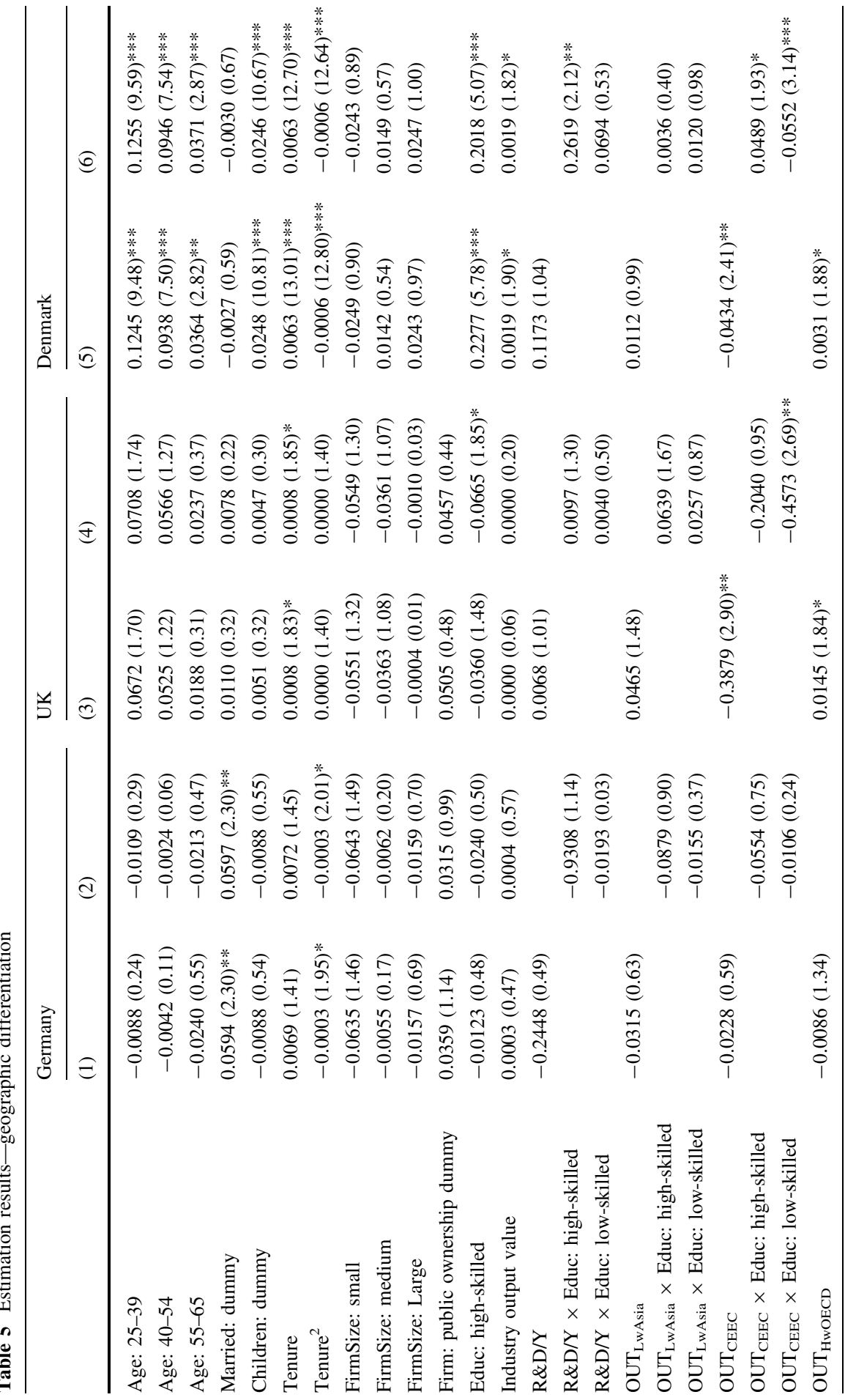




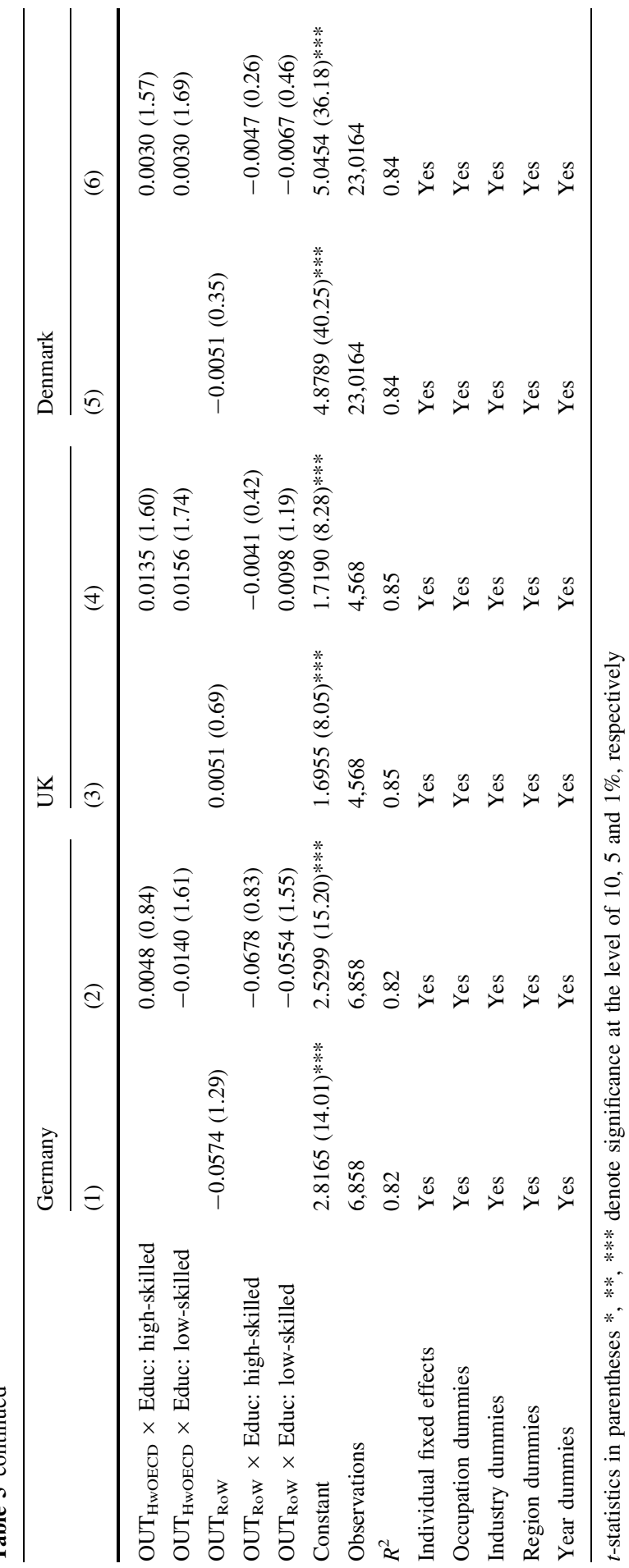


heterogeneity in the activities that are outsourced we distinguish outsourcing to CEEC from outsourcing to low-wage Asia (LwAsia), high-wage OECD (HwOECD) countries and some remaining RoW category. While outsourcing to CEEC and LwAsia is likely to include outsourcing of many low-skilled manufacturing activities the latter group of countries contains outsourcing mainly to other developed countries and, therefore, the type of outsourcing should be considered different. Table 5 presents regression results where we split up the outsourcing variable by broad region, and also allow for differential effects according to skill levels.

Results for Germany (column 1) show that when decomposing outsourcing by region the wage effects of outsourcing cannot be identified with sufficient precision. For the UK (Table 5, column 3) we now, however, find a sizable negative and statistically significant wage effect of outsourcing to CEEC. An one percentage point increase in the average intensity of outsourcing to CEEC ceteris paribus lowers UK manufacturing wages by about 38 percent. To put this into perspective, according to Table $3 \mathrm{UK}$ outsourcing to CEEC increased by 0.07 percentage points. Thus the cumulative effect of outsourcing to CEEC is very modest wage reduction of 2.7 percent. In comparison, outsourcing to high-wage OECD countries is found to yield weakly statistically significant positive wage effects. According to Table 3 UK outsourcing to high-wage OECD countries increased by 1.2 percentage points. Thus, UK manufacturing wages are cumulatively raised by modest 2.6 percent. Furthermore, outsourcing to LwAsia and RoW also appears to raise average UK wages. However, the effects can only be estimated with insufficient precision.

For Denmark we also find a statistically significant negative wage effect of outsourcing to CEEC (Table 5, column 5). According to Table 3 Danish outsourcing to CEEC increased by 0.04 percentage points. Thus, the cumulative wage effect of of outsourcing to CEEC is only -0.2 percent and economically negligible.

Nevertheless, simply looking at homogenous outsourcing masks important differences in effects depending on individual skills. In a next step we therefore interact geographically decomposed outsourcing with educational attainment to capture potentially different effects across skill groups. The respective results are reported in columns (2), (4) and (6) in Table 5.

For Germany, although the coefficients of outsourcing partly are sizable (see column 2) we cannot reject their insignificance within reasonable confidence bounds suggesting that the demand effects of outsourcing are fairly heterogenous across individuals irrespective of the outsourcing region.

For the UK, however, we find low-skilled workers to experience statistically significant wage cuts due to outsourcing to CEEC (see Table 5, column 4). The 0.07 percentage point increase of UK outsourcing towards CEEC lowers wages of lowskilled workers by about 3 percent. At the same time there is some evidence that also high-skilled workers experience wage cuts due to outsourcing to CEEC, the effect, however, cannot be identified with sufficient precision.

Finally, for Denmark (column 6) we find a negative statistically significant effect of outsourcing to CEEC on low-skilled workers wages and a positive statistically 
significant wage effect for high-skilled workers. Cumulatively, increased outsourcing towards CEEC lowered low-skilled wages by only 0.2 percent while the respective cumulative effect for high-skilled workers is a 0.2 percent wage increase. Albeit statistically significant coefficients, both effects are negligible in an economic sense. Other types of outsourcing do not appear to have any statistically significant effect on either skilled or unskilled workers.

Recall that one possible expectation concerning the mediating impact of labour market institutions on outsourcing was that wages should be least sensitive to outsourcing in Denmark, since wages are set in negotiations between unions and firms, while employment protection is low so that any adjustments are more likely to go through job separations. By contrast we argued that wages in Germany and the UK could be more responsive to outsourcing.

First of all, we find that low-skilled workers in all three countries are likely to suffer negative wage effects, in the case of the UK and Denmark particularly from outsourcing to CEEC. In line with our intuition wage effects of outsourcing in Denmark are significantly lower (if not negligible) than those in Germany and the UK. However, wage cuts due to outsourcing are very small even in the UK and Germany. One interesting result is that we find a positive, small but not negligible wage effect of outsourcing for high-skilled workers in the UK which, arguably, is in line with the idea of more flexibel wage setting institutions in the UK. However, overall we conclude that our results only lend weak support for simple intuition regarding the mitigating impact of labour market institutions.

\section{Conclusion}

This paper studies the impact of international outsourcing on individual wages in Germany, the UK and Denmark. To do so we use individual-level wage data for the three countries and construct comparable measures of outsourcing at the industry level, distinguishing outsourcing to Central and Eastern Europe from other countries. While our discussion of labour market institutions may suggest an intuitive predication that there should be differences in effects across countries, our empirical analysis, based on estimating the same specification for the three countries, shows that the effects are, actually, quite similar and fairly small. Lowskilled workers experience reductions in real wages, in the UK particular through outsourcing to Central and Eastern European Countries. There is also some evidence that high-skilled workers benefit through higher wages at least in the UK. This suggests that the relationship between labour market institutions, outsourcing and wages is more complex than our simple intuitive discussion. More theoretical work is needed to pin down the exact nature of the relationship, in order to get a better understanding of the effects of outsourcing on wages under different institutional settings.

Acknowledgments Financial support from the Economic Policy Research Network and the Leverhulme Trust (Grant No. F114/BF) is gratefully acknowledged. We would like to thank participants at the 2007 Zeuthen Workshop, University of Copenhagen for valuable comments. Holger Görg is also affiliated with GlobID, Aarhus School of Business/University of Aarhus. 
Open Access This article is distributed under the terms of the Creative Commons Attribution Noncommercial License which permits any noncommercial use, distribution, and reproduction in any medium, provided the original author(s) and source are credited.

\section{References}

Amiti, M. \& Wei S. J. (2009). Service offshoring and productivity: Evidence from the US. The World Economy, 32(2), 203-220.

Arndt, S. W. (1997). Globalization and the open economy. North American Journal of Economics and Finance, 8(1), 71-79.

Arndt, S. W. (1999). Globalization and economic development. The Journal of International Trade and Economic Development, 8(3), 309-318.

Bender, S., Dustmann, C., Margolis, D., \& Meghir, C. (2002). Worker displacement in France and Germany. In P. J. Kuhn (Ed.), Losing work, moving on: International perspectives on worker displacement. W.E. Upjohn Institute for Employment Research.

Borland, J., Gregg, P., Knight, G., \& Wadsworth, J. (2002). They get knocked down. Do they get up again? In P. J. Kuhn (Ed.), Losing work, moving on: International perspectives on worker displacement. W.E. Upjohn Institute for Employment Research.

Campa, J., \& Goldberg, L. S. (1997). The evolving external orientation of manufacturing industries: Evidence from four countries. Federal Reserve Bank of New York Economic Policy Review, 3, 53-81.

Feenstra, R. C., \& Hanson, G. H. (1996). Globalization, outsourcing, and wage inequality. American Economic Review, 86(2), 240-245.

Feenstra, R. C., \& Hanson, G. H. (1999). The impact of outsourcing and high-technology capital on wages: Estimates for the United States, 1979-1990. Quarterly Journal of Economics, 114(3), 907-941.

Geishecker, I. (2006). Does outsourcing to Central and Eastern Europe really threaten manual workers' jobs in Germany? The World Economy, 29, 559-583.

Geishecker, I., \& Görg, H. (2008). Winners and losers: A micro-level analysis of international outsourcing and wages. Canadian Journal of Economics, 41, 243-270.

Görg, H., Hanley, A., \& Strobl, E. (2008). Productivity effects of international outsourcing: Evidence from plant level data. Canadian Journal of Economics, 41, 670-688.

Haisken-DeNew, J. P., \& Frick, J. R. (2003). Desktop companion to the German Socio-Economic Panel. DIW Berlin, manual (http://www.diw.de/deutsch/sop/service/dtc/dtc.pdf).

Haisken-DeNew, J. P., \& Hahn, M. (2006). PanelWhiz: A flexible modularized stata interface for accessing large scale panel data sets. Mimeo (http://www.PanelWhiz.eu).

Hijzen, A., Görg, H., \& Hine, R. C. (2005). International outsourcing and the skill structure of labour demand in the United Kingdom. Economic Journal, 115(506), 861-879.

Jones, R. W., \& Kierzkowski, H. (2001). A framework for fragmentation. In S. W. Arndt, \& H. Kierzkowski (Eds.), Fragmentation: New production patterns in the world economy. Oxford: Oxford University Press.

Krugman, P. (1995). Growing world trade: Causes and consequences. Brookings Papers on Economic Activity, 1, 327-377.

Kohler, W. (2004). International outsourcing and factor prices with multistage production. Economic Journal, 114, C166-C185.

Moulton, B. (1990). An illustration of the pittfall in estimating the effects of aggregate variables in micro units. Review of Economics and Statistics, 72, 334-338.

Munch, J. R., \& Skaksen, J. R. (2009). Specialization, outsourcing and wages. Review of World Economics/Weltwirtschaftliches Archiv, 145(1), 57-73.

Nickell, S., Nunziata, L., Ochel, W. (2005). Unemployment in the OECD since the 1960s. What do we know? Economic Journal, 115, 1-27.

OECD (1997). OECD employment outlook 1997. Paris: OECD.

OECD (2005). OECD employment outlook 2005. Paris: OECD.

Yeats, A. J. (2001). Just how big is global production sharing? In S. W. Arndt, \& H. Kierzkowski (Eds.), Fragmentation: New production patterns in the world economy. Oxford: Oxford University Press. 